\title{
Sonographic and histopathological correlation and evaluation of endometrium in perimenopausal women with abnormal uterine bleeding
}

\author{
Shobha S. Pillai* \\ Department of Obstetrics \& Gynecology, Cochin Medical College, Cochin, Kerala, India \\ Received: 25 December 2013 \\ Accepted: 6 January 2014 \\ *Correspondence: \\ Dr. Shobha S. Pillai, \\ E-mail: dr.shobha@hotmail.com \\ (C) 2014 Pillai SS. This is an open-access article distributed under the terms of the Creative Commons Attribution Non- \\ Commercial License, which permits unrestricted non-commercial use, distribution, and reproduction in any medium, \\ provided the original work is properly cited.
}

\begin{abstract}
Background: Abnormal Uterine Bleeding (AUB) in perimenopausal women accounts for about $70 \%$ of gynaecologic Outpatient Department visits. This assumes significance in view of the fact that AUB in this age group may be the only clinical sign of endometrial cancer. Objective of current study was to study the various types of menstrual abnormalities prevalent in perimenopausal women and to correlate the transvaginal ultrasonographic (TVUS) findings of endometrial thickness and pattern with the histopathological examination (HPE) of the Endometrium.

Methods: Retrospective study was carried out on 88 women in the perimenopausal age group (40 to 51 years). All the women were clinically evaluated. TVUS study of endometrial pattern and thickness was done followed by Dilatation and Curettage (D\&C) and HPE of the endometrial curettings.

Results: From the sample set, $40 \%$ belonged to the age group of 48 to 51 years and $46.5 \%$ patients presented with menstrual complaints of menorrhagia, which accounts for the most common menstrual complaint. $70.5 \%$ of the patients in the study group were para 2 or less. Fibroid uterus was the commonest uterine pathology detected in $55.7 \%$ of the patients. $46.5 \%$ of patients had endometrial thickness in the range 5 to $9.9 \mathrm{~mm}$. Most common finding on HPE was proliferative endometrium. $4.5 \%$ of cases revealed endometrial malignancy.

Conclusions: In perimenopausal women with AUB, TVUS should be the investigation of choice due to its convenience, accuracy and non-invasiveness. In patients with hyperplastic endometrium and/ or endometrial thickness greater than $8 \mathrm{~mm}$, a histopathological study of the endometrium is warranted to rule out atypical changes or endometrial malignancy.
\end{abstract}

Keywords: Abnormal uterine bleeding, Histopathological examination, Transvaginal sonography, Menorrhagia, Endometrial thickness, Dilatation \& curettage

\section{INTRODUCTION}

In 2001, the Stages of Reproductive Aging Workshop (STRAW) defined 'perimenopause' as the period beginning with menopausal transition and ending 12 months after the last menstrual period. ${ }^{1,2}$ This may last for 4-8 years. During this period, the endocrinological, biological and clinical features of approaching menopause commence. The perimenopause is often characterised by menstrual cycle irregularities in frequency and volume, due to fluctuating estrogen levels. These changes are unpredictable and are unique for each woman. Although irregular bleeding patterns are a normal and expected part of perimenopause, the incidence of uterine pathology and associated medical complications also increase in this age group. ${ }^{3}$ Of equal importance is the impact of this abnormal blood loss on the quality of the woman's life.

Long anovulatory periods with unopposed estrogen stimulation may result in endometrial hyperplasia, thus increasing the risk of endometrial cancers. Therefore, 
AUB in the perimenopausal period assumes significance. AUB accounts for about $70 \%$ of all gynaecologic outpatient visits in the perimenopausal women. ${ }^{4}$

The TVUS is a simple and non-invasive diagnostic modality of studying the endometrial pattern and its thickness accurately, and at the same time to exclude organic pathology in cases of AUB. The high frequency transducer placed nearer to the region of interest permits better visualisation of the uterus and the endometrium. ${ }^{5}$

$\mathrm{D} \& \mathrm{C}$ is a simple day case procedure for histological evaluation of the endometrium and remains the standard diagnostic procedure for the assessment of abnormal uterine bleeding and for early detection of precancerous lesions like atypical endometrial hyperplasia. It was once considered as the gold standard of investigating patients with AUB, but it has the drawback of being a blind procedure with a chance of missing a small or focal lesion. ${ }^{6}$

However, together with TVUS the D\&C still remains a very cost effective, practical and dependable approach for investigating AUB. In addition, accurate histopathological diagnosis also facilitates the implementation of optimal treatment strategies. The present study aims to correlate the clinical findings with sonographic assessment and histopathology of the endometrium.

\section{METHODS}

The work presented in this article is a retrospective study conducted at Cochin Medical College - a tertiary level teaching hospital in Cochin, Kerala, India. A random sample of 88 women in the perimenopausal age group of 40 to 51 years was included in the study. These women reported with AUB during the period June 2012 to November 2013.

Detailed history of menstrual abnormalities, duration of complaints, obstetric, medical, surgical history and details of previous treatment taken were noted. All the women were clinically evaluated - general, systemic and gynaecological examinations were carried out. All relevant investigations and pre-anaesthetic check-ups were done.

TVUS was performed in all these women using ultrasonography machine GE LOGIQ 500 MD MR3 and a vaginal probe of $7.5 \mathrm{MHz}$. Endometrial thickness was measured as maximal double layer thickness in midsagittal section at the thickest area of the endometrium near the fundus, including the outermost border of both sides of the endometrium. All the scans were performed by experienced sonologists in the medical college. A D\&C and HPE of the endometrium were scheduled within $24-48 \mathrm{hr}$ of the TVUS as an inpatient procedure. The menstrual abnormalities were correlated with the endometrial thickness on TVUS and the histopathology report and the results were analysed.

\section{RESULTS}

Table 1 shows the age wise distribution of patients. Patients in the age group 40 - 51 were studied. There was almost equal distribution of patients in the $44-47$ and 48 - 51 age group.

Table 1: Distribution of patients according to age.

\begin{tabular}{|lll|}
\hline Age group & No. of patients & Percentage (\%) \\
\hline $40-43$ & 21 & 23.8 \\
\hline $44-47$ & 32 & 36.4 \\
\hline $48-51$ & 35 & 39.8 \\
\hline
\end{tabular}

The study was carried out in Kerala where there is a high degree of acceptance of family planning methods. Hence, $70.45 \%$ of patients were para 2 or less (Table 2).

Table 2: Distribution of patients according to parity.

\begin{tabular}{|lll|}
\hline Parity & No. of patients & Percentage (\%) \\
\hline Nulliparous & 4 & 4.5 \\
\hline Parity $\leq 2$ & 62 & 70.5 \\
\hline Parity $>2$ & 22 & 25 \\
\hline
\end{tabular}

The majority of women $(46.6 \%)$ presented with menorrhagia and $19 \%$ with menometrorrhagia. The most common associated symptom was dysmenorrhoea. $15 \%$ of patients presented with features of metropathia periods of amenorrhoea of 3 to 6 months followed by prolonged heavy bleeding, a feature most characteristic of perimenopausal anovulatory cycles (Table 3 ).

Table 3: Distribution of patients according to presenting menstrual complaint.

\begin{tabular}{|lll|}
\hline Menstrual complaint & No. of patients & Percentage \\
\hline Menorrhagia & 41 & 46.6 \\
\hline Menometrorrhagia & 19 & 21.6 \\
\hline Metropathia & 15 & 17.0 \\
\hline Polymenorrhoea & 10 & 11.4 \\
\hline $\begin{array}{l}\text { Postcoital bleeding / } \\
\text { premenstrual spotting }\end{array}$ & 3 & 3.4 \\
\hline
\end{tabular}

On clinical examination and ultrasonographic confirmation $55.7 \%$ of patients presented with fibroid uterus, $29.5 \%$ of cases had no obvious organic pathology, i.e., dysfunctional uterine bleeding while in $7.9 \%$ of cases the cause was endometrial polyp (Table 4).

TVUS examination revealed 41 out of the 88 patients to have endometrial thickness between 5 and $9.9 \mathrm{~mm}$, thus accounting for $46.6 \%$ of patients. $22.7 \%$ patients had endometrial thickness between 10 and $14.9 \mathrm{~mm}$ (Table 5). 
Table 4: Distribution of patients according to uterine pathology detected on USG.

\begin{tabular}{|lll|}
\hline Pathology & No. of patients & Percentage (\%) \\
\hline Fibroid & 49 & 55.7 \\
\hline Adenomyosis & 6 & 6.8 \\
\hline DUB & 26 & 29.5 \\
\hline Endometrial polyp & 7 & 8.0 \\
\hline
\end{tabular}

Table 5: TVUS findings of endometrial thickness.

\begin{tabular}{|lll|}
\hline $\begin{array}{l}\text { Endometrial } \\
\text { thickness }(\mathbf{m m})\end{array}$ & No. of patients & Percentage $(\%)$ \\
\hline $1-4.9$ & 3 & 3.4 \\
\hline $5-9.9$ & 41 & 46.6 \\
\hline $10-14.9$ & 20 & 22.7 \\
\hline $15-19.9$ & 15 & 17.1 \\
\hline$\geq 20$ & 9 & 10.2 \\
\hline
\end{tabular}

Histopathological examination of the endometrial curettings revealed 24 patients to have proliferative endometrium followed by 20 patients reported to have disordered proliferative endometrium. Hyperplastic changes were found in 17 patients, though only 5 of them had complex hyperplasia with atypia. Adenocarcinoma of the endometrium was detected in 4 patients. Proliferative endometrium was the most common histological pattern detected. Disordered proliferation considered as an intermediate step between normal proliferative endometrium and endometrial hyperplasia was detected in $22.7 \%$ of the patients (Table 6 ).

Table 6: Histopathology examination report.

\begin{tabular}{|ll|l|}
\hline Histopathology findings & $\begin{array}{l}\text { No. of } \\
\text { patients }\end{array}$ & $\begin{array}{l}\text { Percentage } \\
(\%)\end{array}$ \\
\hline Proliferative & 24 & 27.2 \\
\hline Secretory & 16 & 18.2 \\
\hline Disordered proliferation & 20 & 22.7 \\
\hline $\begin{array}{l}\text { Simple hyperplasia } \\
\text { without atypia }\end{array}$ & 9 & 10.2 \\
\hline $\begin{array}{l}\text { Complex hyperplasia } \\
\text { without atypia }\end{array}$ & 3 & 3.4 \\
\hline $\begin{array}{l}\text { Complex hyperplasia } \\
\text { with atypia }\end{array}$ & 5 & 5.7 \\
\hline Atrophic & 4 & 4.6 \\
\hline Endometrial carcinoma & 4 & 4.6 \\
\hline $\begin{array}{l}\text { Tissue inadequate for } \\
\text { diagnosis }\end{array}$ & 3 & 3.4 \\
\hline
\end{tabular}

When the presenting menstrual complaints of the patients were correlated with their histopathological examination report, it was found that out of the 41 patients who presented with menorrhagia, 15 had proliferative endometrium and 8 showed disordered proliferation of endometrium, thus making proliferative endometrium the most common finding in menorrhagia. Among the 15 patients with metropathia, 7 showed hyperplastic changes of which 4 were complex hyperplasia with atypia (Table 7).

Table 7: Correlation between HPE findings and menstrual complaints.

\begin{tabular}{|c|c|c|c|c|c|}
\hline \multirow[b]{2}{*}{$\begin{array}{l}\text { Histopathology } \\
\text { findings }\end{array}$} & \multicolumn{5}{|c|}{ Menstrual complaints } \\
\hline & Menorrhagia & Menometrorrhagia & Metropathia & Polymenorrhoea & $\begin{array}{l}\text { Postcoital } \\
\text { bleeding / } \\
\text { premenstrual } \\
\text { spotting }\end{array}$ \\
\hline Proliferative & 15 & 3 & 1 & 5 & 0 \\
\hline Secretory & 9 & 5 & 1 & 1 & 0 \\
\hline $\begin{array}{l}\text { Disordered } \\
\text { proliferation }\end{array}$ & 8 & 6 & 4 & 2 & 0 \\
\hline $\begin{array}{l}\text { Simple hyperplasia } \\
\text { without atypia }\end{array}$ & 4 & 3 & 1 & 1 & 0 \\
\hline $\begin{array}{l}\text { Complex hyperplasia } \\
\text { without atypia }\end{array}$ & 1 & 0 & 2 & 0 & 0 \\
\hline $\begin{array}{l}\text { Complex hyperplasia } \\
\text { with atypia }\end{array}$ & 0 & 0 & 4 & 1 & 0 \\
\hline Atrophic & 2 & 0 & 0 & 0 & 2 \\
\hline $\begin{array}{l}\text { Endometrial } \\
\text { carcinoma }\end{array}$ & 0 & 1 & 2 & 0 & 1 \\
\hline $\begin{array}{l}\text { Tissue inadequate for } \\
\text { diagnosis }\end{array}$ & 2 & 1 & 0 & 0 & 0 \\
\hline Total & 41 & 19 & 15 & 10 & 3 \\
\hline
\end{tabular}


When the TVUS findings of the endometrial thickness were correlated with the Histopathological examination report, it was found that out of the 41 patients with endometrial thickness between 5 and $9 \mathrm{~mm}, 22$ showed proliferative changes which included disordered proliferation. At endometrial thickness between 15 and
$19.9 \mathrm{~mm}$ hyperplastic changes were the predominant HPE findings with 2 of the patients showing complex hyperplasia with atypia. In patients with endometrial thickness $\geq 20 \mathrm{~mm}$, carcinoma of the endometrium was detected in 3 patients (Table 8 ). In 3 patients, endometrial tissue was found to be inadequate for diagnosis.

Table 8: Correlation between HPE findings and endometrial thickness.

\begin{tabular}{|llllll|}
\hline $\begin{array}{l}\text { Histopathology } \\
\text { findings }\end{array}$ & $\mathbf{1 - 4 . 9}$ & $\mathbf{5 - 9 . 9}$ & $\mathbf{1 0}-\mathbf{1 4 . 9}$ & $\mathbf{1 5}-\mathbf{1 9 . 9}$ & $\mathbf{2 0}$ \\
\hline Proliferative & 0 & 12 & 7 & 5 & 0 \\
\hline Secretory & 0 & 9 & 7 & 0 & 0 \\
\hline $\begin{array}{l}\text { Disordered } \\
\text { proliferation }\end{array}$ & 0 & 10 & 2 & 5 & 3 \\
\hline $\begin{array}{l}\text { Simple hyperplasia } \\
\text { without Atypia }\end{array}$ & 0 & 7 & 1 & 2 & 0 \\
\hline $\begin{array}{l}\text { Complex hyperplasia } \\
\text { without atypia }\end{array}$ & 0 & 0 & 0 & 2 & 0 \\
\hline $\begin{array}{l}\text { Complex hyperplasia } \\
\text { with atypia }\end{array}$ & 0 & 0 & 1 & 0 & 3 \\
\hline Atrophic & 1 & 2 & 0 & 1 & 0 \\
\hline $\begin{array}{l}\text { Endometrial } \\
\text { carcinoma }\end{array}$ & 0 & 0 & 0 & 0 & 3 \\
\hline $\begin{array}{l}\text { Tissue inadequate } \\
\text { for diagnosis }\end{array}$ & 2 & 1 & 20 & 15 & 0 \\
\hline Total & 3 & 41 & & 0 & 9 \\
\hline
\end{tabular}

\section{DISCUSSION}

As AUB is the problem responsible for most of the gynaecologic consultations in the perimenopausal age group, thorough evaluation is a must especially in this age group to rule out endometrial cancer or its precursor lesion - endometrial hyperplasia. Sonographic and histological assessment of the endometrium is the corner stone of diagnosis in the current practice.

In the present study menorrhagia was the most common clinical presentation seen in $46.5 \%$ of cases followed by menometrorrhagia at $21.5 \%$ which is very similar to the study by Jetley et al. in which they studied 219 perimenopausal women in New Delhi. ${ }^{7}$ Proliferative endometrium was the most common finding on histopathological examination. The mean endometrial thickness was $7.45 \mathrm{~mm}$ in the proliferative phase and $12.45 \mathrm{~mm}$ in the secretory phase. These findings are consistent with similar studies carried out by Acharya Veena et al. in 2003. ${ }^{8}$ In the earlier mentioned study by Jetley et al. ${ }^{7}$ however, secretory endometrium was the most common finding at $32.4 \%$ followed by proliferative endometrium. In the present study, complex hyperplasia with atypia or malignancy was not noted at endometrial thickness less than $14.9 \mathrm{~mm}$. All the 9 cases that showed abnormality on histopathological evaluation had endometrial thickness greater than $15 \mathrm{~mm}$. This study thus corroborated the findings of similar study done by Aliya Aslam et al. in 2009. ${ }^{9}$ Their study found that no major endometrial pathology is detected when endometrial thickness is less than $14 \mathrm{~mm}$. Study by Machado et al in 2005 concluded that endometrial thickness less than $5 \mathrm{~mm}$ did not need D\&C as none of these patients had atypia or malignancy which is also corroborated in the present study. ${ }^{10,11}$

The study by Chatapavit et al. concluded that endometrial thickness of $8 \mathrm{~mm}$ or less is less likely to be associated with malignant pathology in perimenopausal women with abnormal uterine bleeding. ${ }^{12}$ There is no clear definition of what constitutes an abnormal endometrial thickness in the still menstruating perimenopausal woman. The upper limit for normal endometrial thickness remains controversial, but most studies have reported transvaginal sonographic endometrial thickness. $8 \mathrm{~mm}$ as the abnormal cut off value, necessitating further investigations. ${ }^{13}$ In the perimenopausal cycles, there is unopposed estrogen stimulation which leads to hyperplasia of the endometrium which can progress to endometrial cancer. History of irregular cycles, polycystic ovarian syndrome, and anovulatory cycles are risk factors in the progression of endometrial hyperplasia. The risk of development of endometrial cancer is $29 \%$ in patients with complex atypical hyperplasia and $2 \%$ in patients with hyperplasia but without atypia. ${ }^{14}$ This is to emphasise the fact that all patients with endometrial hyperplasia diagnosed on TVUS must have a thorough endometrial evaluation by D\&C. ${ }^{15,16}$ In 3 patients, the endometrial curettings were scanty and reported as inadequate for diagnosis. In a 
study conducted at the School of Medicine, Philadelphia, the negative predictive value of endometrial tissue reported as inadequate for endometrial neoplasia was determined. This study concluded that inadequate endometrial sample can be considered to rule out endometrial neoplasia because of its high negative predictive value. $^{17}$

\section{CONCLUSIONS}

In perimenopausal women presenting with AUB, a speculum examination and palpation should always be performed first.

TVUS is recommended as a first line diagnostic tool as it is relatively inexpensive, safe and non-invasive. It will not only reveal endometrial thickness but also other pelvic pathology.

The primary indication for invasive methods like D\&C should be in cases with abnormal thickness of endometrium $>8 \mathrm{~mm}$ or inconclusive TVUS in order to obtain endometrial tissue to exclude precancerous lesion or endometrial cancer.

\section{ACKNOWLEDGEMENTS}

The author wishes to acknowledge help rendered by Dr. Chinchu Sunny and Dr. Sabreena in collecting data from the medical records. The author also wishes to record deep sense of gratitude to the Principal, Cochin Medical College for providing necessary facilities to carry out the research.

Funding: No funding sources Conflict of interest: None declared

Ethical approval: Not required

\section{REFERENCES}

1. Soules MR, Sherman S, Parrott E. Stages of reproductive aging workshop (STRAW). J. Womens Health, Gender Based Med. 2001;10:843-8.

2. Awwad JT, Toth TL, Schiff I. Abnormal uterine bleeding in the perimenopause. Int $\mathbf{J}$ Fertil. and Menopausal Stud. 1993;38(5):261-9.

3. Speroff L, Fritz MA. Menopause and the perimenopausal transition, clinical endocrinology. In: Speroff L, Fritz MA, eds. Clinical gynecologic endocrinology and infertility. 7th ed. Philadelphia, London: Lippincott Williams \& Wilkins; 2005: 628.

4. Grimes DA. Diagnostic dilatation and curettage: a reappraisal. Am J Obstet Gynecol. 1982;142(1):1-6.

5. Goldstein SR. The endometrial echo revisited: have we created a monster? Am J Obstet Gynecol. 2004;191:1092-6.
6. Albert JR, Hull SK, Wesley RM. Abnormal uterine bleeding. Am Fam Phys. 2004;69:1915-26.

7. Jetley S, Rana S, Jairajpuri ZS. Morphological spectrum of endometrial pathology in middle aged women with atypical uterine bleeding - a study of 219 cases. J Midlife Health. 2013;4:216-20.

8. Acharya V, Mehta S, Rander A. Evaluation of dysfunctional uterine bleeding by TVS, hysteroscopy and histopathology. J Obstet Gynecol India. 2003;53:170-7.

9. Aliya Aslam, Gazala. Role of TVS in cases of abnormal uterine bleeding. Profesional Med J. 2009;(16)1:127-34.

10. Machado LS, Mathew M, Al-Hassani A, Vaclavinkova V. Correlation of endometrial thickness, cycle day and histopathology in women with abnormal uterine bleeding. Saudi Med J. 2005;26(2):260-3.

11. American Cancer Society. The role of transvaginal ultrasonography in the evaluation of postmenopausal bleeding. ACOG Committee Opinion No. 440. American College of Obstetricians and Gynecologists. Obstet Gynecol. 2009;114:409-11.

12. Getpook C., Wattanakumtornkul S. Endometrial thickness screening in premenopausal women with abnormal uterine bleeding. Journal of Obstetrics and Gynaecology Research. 2006;32:588-92.

13. Parihar Mandakini, Parihar Anand. Peri- and postmenopausal uterine bleeding transvaginal ultrasound with hysterosonography and diagnostic correlation with hysteroscopy. Donald School Journal of Ultrasound in Obstetrics \& Gynecology. 2012;5(4):343-52.

14. Kurman RJ, Norris HJ. Endometrial hyperplasia and related cellular changes. Blaustein's pathology of female genital tract. In: Wilkinson E, eds. Atlas of Tumor Pathology. Tumors of the Cervix, Vagina and Vulva, Third Series. 4th ed. New York, USA: Silverberg publication; 1994: 411-437.

15. Archana B, Michelle F. Evaluation and histopathological correlation of abnormal uterine bleeding in perimenopausal women. J Bombay Hospital. 2010;52:69-72.

16. Doraiswami S, Johnson $\mathrm{T}$, Rao S, Rajkumar A Vijayaraghavan J, Panicker V. Study of Endometrial Pathology in Abnormal Uterine Bleeding. J Obstet Gynaecol India. 2011 August;61(4):426-30.

17. Harmanli OH, Shunmugham S, Shen T, Houck CL, Chatwani AJ. The negative predictive value of inadequate endometrial biopsy in diagnosing endometrial neoplasia. J Obstet Gynecol Surg 2004;20(1):13-6.

DOI: $10.5455 / 2320-1770 . i j r \operatorname{cog} 20140323$

Cite this article as: Pillai SS. Sonographic and histopathological correlation and evaluation of endometrium in perimenopausal women with abnormal uterine bleeding. Int J Reprod Contracept Obstet Gynecol 2014;3:113-7. 